\title{
Private security beyond private military and security companies: exploring diversity within private-public collaborations and its consequences for security governance
}

\author{
Oldrich Bures $^{1,2} \cdot$ Helena Carrapico ${ }^{3}$
}

Published online: 13 October 2016

(C) Springer Science+Business Media Dordrecht 2016

\begin{abstract}
The aim of this special issue is to widen the existing debates on security privatization by looking at how and why an increasing number of private actors beyond private military and/or security companies (PMSCs) have come to perform various security related functions. While PMSCs produce security for profit, most other private sector actors make profit by selling goods and services that were originally not connected with security in the traditional understanding of the term. However, due to the continuous introduction of new legal and technical regulations by public authorities, many non- security related private businesses nowadays have to perform at least some security functions. Little research, however, has been done thus far, both in terms of security practices of non- security related private businesses and their impact on security governance. This introduction explains how this special issue contributes to closing this glaring gap by 1 ) extending the conceptual and theoretical arguments in the existing body of literature; and 2) offering a range of original case studies on the specific roles of non- security related private companies of all sizes, areas of businesses, and geographic origin.
\end{abstract}

Helena Carrapico

h.farrand-carrapico@aston.ac.uk

Oldrich Bures

oldrich.bures@mup.cz

1 Present address: Center for Security Studies, Metropolitan University Prague, Dubečská 900/10, Prague 100 31, Czech Republic

2 Institute of Hazard, Risk and Resilience, Durham University, Lower Mountjoy South Road, Durham DH1 3LE, UK

3 School of Languages and Social Sciences, Aston University, Aston Triangle, Birmingham B4 7ET, UK 


\section{Introduction to the activities of the non-security related private companies}

Experts in several academic disciplines have already investigated the growing role of private companies in the provision of security [1-11]. Empirically, this topic can be found in the recent literature in International Relations, Security Studies, Criminology, and Sociology. A substantial part of this literature, however, focuses only on those private actors that sell various security services for profit as the primary line of their business - e.g. the private military and/or security companies (PMSCs). The usage of PMSCs increased exponentially in the past two decades to complement traditional military forces in conflict scenarios, as well as domestic forces in ensuring law and order. Examples of such PMSCs include, for instance the British company Aegis Defence Services, which was contracted by the US department of Defense to provide support in the Iraq and Afghanistan wars [12], and the American company G4S plc, whose services are now widely widespread at airports, land borders, ports, financial institutions, governmental institutions, industry, and prisons [13]. In order to convey an overall impression of the vast scope and scale of private security provision, it is worth noting that the massive use of PMSCs in recent armed conflicts prompted one informed observer to conclude that " $[\mathrm{t}]$ he private sector is so firmly embedded in combat, occupation and peacekeeping duties that the phenomenon may have reached the point of no return: even the US military would struggle to wage war without it" [14]. In other words, the much-cited Weberian definition of the Westphalian state as the only human community that (successfully) claims the monopoly of the legitimate use of physical force within a given territory, no longer reflects the realities of many contemporary armed conflicts. Given the focus of this special issue, however, there is neither the space nor the need for a comprehensive review of this literature (for further analyses of PMSCs, please see [15-20]).

As mentioned above, given that the existing literature focuses primarily on those private actors that sell various security services for profit as their primary line of business, it neglects the mushrooming security practices of various non- security related private businesses (e.g. financial institutions, transportation companies, utility services providers, and infrastructure owners/operators), which make profit by selling goods and services that are unrelated with security in the traditional understanding of the term. Thus, the primary aim of this special issue is to widen the existing debates on security privatization by looking at how and why an increasing number of private actors beyond PMSCs have come to perform various security-related functions. As editors, we believe that adopting a broader perspective, beyond private military companies, contributes to our understanding of the subject by permitting the individual contributors to this special issue to develop ground-breaking work by, firstly, exploring a range of case studies pointing out the growing presence of the private sector in security-related activities and critical infrastructures, and the consequent transfer of security responsibilities from the public sector to the non-security related private sector. Secondly, we specifically asked the contributors to draw upon their diverse disciplinary expertise and focus on possible ways to approach the conceptualization of the various security roles and practices of non- security related businesses.

In order to ensure unity of purpose, a special issue meeting was held in June 2015 in the context of a one-day workshop at the British International Studies Association annual convention. The objectives of the workshop were to 1) map the extent to which 
security is being outsourced to private companies beyond PMSCs; 2) assess the social, political and economic consequences of the way security provision is evolving; and 3) explore the plausible conceptual and theoretical frameworks for analysis of the growing rule of non- security related private businesses in security governance.

The present special issue is the result of those fruitful exchanges: a volume that presents the views of a diverse group of scholars in terms of disciplines, primary field of research, epistemological and ontological approaches, academic seniority, institutional affiliation, and nationality, in addition to offering original case studies on the specific roles of non- security related private companies of all sizes, areas of business, and geographic origin. The special issue is composed of six articles, grouped into two sections. The first section explores how public and private security roles are being re-conceptualised within current trends in security governance. By deconstructing the mainstream discourse on the efficiency of public-private collaborations, this section underlines the diversity of security governance arrangements, as well as the recurrent absence of shared priorities and strategies between public and private actors. This section is formed of three articles: the first one, authored by Carrapico and Farrand [21], is entitled 'Dialogue, Partnership and Empowerment for Network and Information Security: The Changing Role of the Private Sector From Regulation Adopters to Regulation Shapers'; the second article, written by Bossong and Wagner [22], focuses on 'Cybersecurity and Public-Private Partnership - a clarification of roles and interactions in the context of the EU'; and the third one, produced by Bures [23], is titled 'Contributions of Private Businesses to the Provision of Security in the EU: Beyond Public-Private Partnerships'.

The second section further explores current security governance by analysing the diversity of security arrangements, which include not only Public- Private Partnerships (PPPs), but also state-based arrangements and fully privatised arrangements, often coexisting within the same territory. This section not only documents existing PPPs, but it also maps the evolution of these fast-changing relations and asks who is in the driving seat of such arrangements. If the public sector is no longer rowing, is it at least still steering? The existence of such diversity leads us to re-think the idea that globalization and its impact on the security environment and market have resulted in the homogenisation of security governance and the approximation of security actors' practices [24]. Furthermore, this second section also analyses the consequences of diverse security arrangements for different areas of activity. In particular, it analyses, firstly, the societal and political outcomes of tasking non- security related businesses with security responsibilities, and, secondly, the consequences of having traditional state sectors become increasingly dependent upon private capabilities and resources. This section is composed of three articles: the first one, which is authored by Aarstad [25], is entitled 'Maritime Security and Transformations in Global Governance'; the second one, written by Biaumet [26], focuses on 'The sentinel and the rebel. Multi-choice policing in Burundi and the state-centered approach of security sector reform '; and the final article, by Saldivar and Price [27], is on 'The Social and Political Impact of the New (Private) National Security: Securitization of immigration in the United States Post 9/11'.

The remainder of this introduction to the special issue seeks to expand on the main themes and trends of these two sections by starting with an analysis of the sectors and roles that are currently being outsourced to private companies beyond PMSC. It then 
turns to how we can begin to conceptualise such trends and concludes with a discussion on the consequences that could emerge from this form of privatization.

\section{What is outsourced to private companies beyond PMSCs?}

This special issue extends the conceptual and theoretical arguments in the emerging body of literature on security provision beyond PMSCs, that indicates that the bulk of private companies' security roles and practices falls under the label of the so-called critical infrastructure. While there is still some debate about what makes a particular infrastructure critical to the extent that its incapacity or destruction would have a debilitating effect on national security, there is a consensus that much of it is owned and/or operated by the private sector [28]. Due to the privatization and deregulation of the public sector since the 1980 s and the globalization processes since the end of the cold war, the private sector controls $85 \%$ of the critical infrastructure in most Western countries [29]. This concentration is based on two factors: 1) the perception that the private sector is better placed to efficiently manage different sectors of activity, including security ones, thanks to its organizational structure and existing expertise [30]; and 2) the enlargement of the concept of critical infrastructure, which evolved from being equated with military structures to being associated with more diverse forms of infrastructure such as economic ones [4].

According to O'Rourke [31], the lists of critical infrastructures have continuously increased since the 9/11 attacks, with key aspects now including agriculture and food systems, energy systems, health care facilities, banking and finance systems, commercial facilities and shipping services, most of which are currently privately owned. ${ }^{1}$ As a consequence, representatives of public security agencies in several Western countries have started to increasingly call upon private companies to participate in the management of various national security issues, with an overall political aim of considerably reducing security risk and making the entire society more resilient and resistant to all kinds of threats, natural disasters and man-made catastrophes [21, 23, 33-35]. According to the former US Secretary of Homeland Security Janet Napolitano, for example, "homeland security ... requires not just a 'whole of government', but a 'whole of nation' approach. In some respects, local law enforcement, community groups, citizens, and the private sector play as much of a role in homeland security as the federal government" (cited in [8], 1).

Several sociology experts consider such statements to be a sign of a larger trend of "responsibilization" whereby individuals, communities, private businesses and other non-state actors "at risk" are increasingly expected to accept substantial responsibility for their own safety and security [36, 37]. As such, security becomes more individualized and market-oriented, whereby "responsible individual and corporate behavior entails installing burglar alarms and surveillance systems, engaging the services of a security company, participating in neighbourhood watches, and other forms of non- or quasi- state-related security behavior" ([1], 67). This trend also explains why

\footnotetext{
${ }^{1}$ Authors such as Bossong [32], however, critically point out that despite the gradual expansion of the concept of Critical Infrastructures, such expansion has not automatically been reflected in operational programmes.
} 
contemporary criminological analyses commonly point to the fragmentation and blurring of the security sector, where public and private actors interact in the provision of security $[9,11]$. While the specifics vary among critical infrastructures, as well as national frameworks, the articles in this special issue confirm that some degree of security pluralisation is clearly discernable across both the specific infrastructures and across national boundaries.

It is therefore important to clarify at this point what we mean by security provision by non-security companies. Following Bures' contribution to this special issue, we argue in favour of focusing primarily on those provisions and/or practices of security that are 1) intentional (e.g. not mere by-products of other business activities); and that 2) directly and/or indirectly address the level of (in-)security in a given environment. As in the case of PMSCs, security provision by non-security companies is also inherently political in the sense that it involves activities that impact the perception and/or provision of security, which has been traditionally conceptualized as a public (rather than private) good. In contrast to PMSCs, however, not all security provision by non-security companies can be described as voluntary. Moreover, unlike the proactive security engagement that is typical of both public security agencies and PMSCs, non-security companies have several other options at their disposal when it comes to responding to various security threats: 1) Business termination; 2) Taking the security risks and running the business as usual; and 3) Transferring the costs related to the threat's occurrence by purchasing insurance $[23,38]$.

\section{Conceptualizing private security beyond PMSCs: public-private partnerships}

In addition to disagreements concerning the impacts and implications of security pluralisation in general, and the growing security role of private companies in particular (see below), social sciences experts share a common challenge when it comes to improving the conceptual basis of their positions and arguments. In contrast, public policy-makers have primarily attempted to push for a greater security role of private companies under the rubric of public-private partnerships (PPPs), which have emerged as a particularly popular option in the last decade [21-23, 38-41]. Albeit originally conceived in the field of administrative reform, in the $1980 \mathrm{~s}$, with the dual aim of debureaucratize public services and promote privatization [18, 42], the concept of PPPs was subsequently utilised within the then new concept of critical infrastructure protection in the 1990s. It was presented as a way to reduce the vulnerability of vital systems to low-probability, yet high-consequence, new security threats [43]. Since 9/11, the popularity of PPPs has risen to the point that they have been described by public officials as the third leg in counterterrorism - the first two being intelligence and surveillance (or technology) ([44], 408).

Several articles in this special issue, however, suggest that the actual security performance of security-related PPPs is subject to debate. For example, Bures [23] argues that PPPs do not always automatically produce the expected win-win solutions, neither for the public nor for the private sector, as there is a dissonance between the "better safe than sorry" logic of public security agencies and the "profit first" logic of 
private companies. As a consequence, unless imposed by command (via legal and/or technical regulations at both the national and international level which, however, fundamentally contradict the non-hierarchical nature of PPPs), some private companies are likely to pursue different options from the ones followed by public agencies, which are tasked with ensuring the maximum possible level of security.

The degree of dissonance between the security logic and the market one, however, is not a static one and is bound to vary considerably according to the area under analysis. As Carrapico and Farrand [21] argue, the relations established between the public and private sides of PPPs in the field of Network and Information Security have evolved considerably over time and so has the perceived dissonance. Companies such as Internet access providers and online service providers have moved from a passive role, as objects of regulation, to an active one, firstly as actors responsible for adopting regulations, and later as shapers of such regulations. Although there is still some concern expressed over such dissonance, the authors clearly indicate that the market logic has spilled over the security one, resulting in the private sector being largely influential within PPPs in this field, which could have serious consequences at the level of their security performance.

Bossong and Wagner [22] explore a similar line of enquiry by studying how PPPs are diversely articulated in the area of cyber security. Their article provides a conceptual mapping of the different forms and kinds of PPPs in the area of cybersecurity, especially in so far as it concerns more regular and publicly known forms of cooperation arrangements in this area, differentiating partnerships from other forms of horizontal coordination or co-regulation between public and private actors. Such distinction allows for a more nuanced understanding of PPPs, underlying how different communities of practice are associated to different normative concerns and priorities, thus contributing to a more advanced conceptualization of the relations between public and private actors in the area of cyber security.

Jointly, the first three articles in this special issue suggest that at least within the European Union, the majority of existing examples of genuine publicprivate cooperation primarily concern cyberspace. This is primarily due to the fact that most cyber security issues transcend not only the public-private divide but also the national borders, thus making most of the national/public security governance measures obsolete. As such, in Bourdieu's terms [45, 46], cyber security is arguably a rather unique field in terms of the distribution of material, cultural and symbolic capital among public and private actors. Thus, more than in other types of critical infrastructures, where public actors are still often the ones with superior cultural and symbolic capital and thus are able to set the rules of the game via legal and/or technical regulation, their actual performance in cyber security often depends on what Bourdieu [46] called having "the feel for the game", e.g. "the actor's ability to comprehend their place within the field and the relative distribution of forms of capital within it" ([1], 105). According to both Bossong and Wagner [22] and Carrapico and Farrand [21], private actors in cyber security often have the upper hand because when dealing with new or advanced cyber threats, public actors often enter the public-private partnerships as the weaker partner, reliant on specialised IT companies to define both the level of vulnerability and appropriate countermeasures. 


\section{New security arrangements and their conceptualizations beyond PPPs}

As PPPs appear to underplay the significant costs related to the adoption and implementation of security policies by non-security private companies, academic experts have recently pondered about alternative conceptual frameworks that may be more suitable for explaining the apparent gap between the security-maximizing logic of public security agencies and the profit-maximizing logic of private companies. For example, in the area of counterterrorism, where "[p]revention, detection and reporting are carried out by private partners, while the public partners have an analytic and repressive task," ([47], 9) several security studies experts suggested that we are witnessing the emergence of new types of security arrangements. Building on Foucault's notion of space, ${ }^{2}$ Wesseling described the European Union's fight against terrorism financing as "a network of all private and public, national and international actors that are responsible for standard setting, decision-making, implementing and/or monitoring the EU's measures to combat terrorism finance" ([49], 2). Similarly, Parker and Taylor suggested that we are witnessing the emergence of "a new security paradigm in which financial borders and parameters are best understood as a 'complex assemblage' in which private financial institutions are in effect, authorized to make security decisions" ([7], 953, also see [1, 2]).

The articles included in this special issue make empirical and conceptual contributions to this growing literature on new security arrangements. Regarding the empirical contribution, Aarstad's article [25] challenges several common wisdoms regarding current maritime governance arrangements. This author argues that due to several recent shifts in private and public governance capabilities in this domain (primarily related to the proliferation of armed private security provision), public actors nowadays facilitate security governance by carving out privileged spheres for commercial industries through their convening capacities, regulatory infrastructure and legitimizing role. This new role as facilitators signals a departure from the classic governance jargons 'rowing' and 'steering', as it does not necessarily imply a sense of control and direction. In particular, the agenda-setting capacities of private actors testify to a re-articulated role for public actors that is centered around convening resources, implementing consensual decisions through the existing regulatory infrastructure and casting a shield of legitimacy on the arrangement and the actors involved. Thus, according to Aarstad, the facilitation by public actors of private actors' participation in the governance arrangement surrounding private maritime security denotes both an active and passive reaction to changes in the globalized security environment in order to remain relevant in contemporary security politics.

Biaumet's article [26] offers an intriguing case study of two grassroots policing arrangements in Burundi - the use of informal 'sentinels', guarding virtually every commercial and domestic buildings in the capital city, and the reconversion of former bandits into security guards in palm oil fields. Their existence challenges the Western notions of 'security governance' and 'security sector reform' and suggests that in postconflict settings, at least two types of 'security governance' coexist - a global security assemblage backboned by donors' discourses on state empowerment and involving

\footnotetext{
${ }^{2}$ According to Foucault, the notion of 'space' does not imply a fixed geographical area, it is rather a constructed transnational "network that connects points and intersects with its own skein" ([48], 22).
} 
coordination processes between formal (or growingly formalized) actors of security; and the local self-policing arrangements falling de facto out-of-scope of any public management. While some recent conceptualizations of security sector reform formally depart from state-centered views of security governance, the case study of Burundi suggests that implementation on the ground still resists holistic approaches of security.

In their article, Saldivar and Price [27] use Securitization Theory to make sense of the evolution of immigration policies in the United States in the aftermath of $9 / 11$ terrorist attacks. They argue that securitization was rendered possible through the perceived threat posed by immigration to national identity and security, with increasing numbers of American citizens worrying about the social cohesion of American culture and about potential terrorist attacks. While mostly focusing on the various impacts of the securitization of immigration (see below), these authors also discuss the crucial role of powerful private actors when it comes to their encouraging of a more securitised state (motivated by primary profit) and their pushing of the public sector towards a growing reliance on the private prison industrial complex.

Finally, Bures [23] explored two alternative conceptual frameworks for analysing the gap between the security-maximizing logic of public security agencies and the profit-maximizing logic of private companies: political corporate social responsibility (PCSR) and resilience. The former comprises a growing number of publications whose authors seek to "normatively prescribe, and positively describe and explain, the political duties and activities of corporations" ([50], [51], 1). In particular, PCSR highlights the relative decline of political and socio-economic steering capacities of Westphalian territorially-bound nation-states vis-à-vis the (global) business actors, which in turn leads to the blurring of traditional boundaries between the political, economic and civil spheres of society [52-54].

The latter concept of resilience is a contested one, but it usually takes into account that 1) it is impossible to guarantee the full protection of all critical infrastructure given its sheer size and the enormous costs that it would involve, and 2) even the best security measures sometimes fail. Its proponents therefore argue that more emphasis should be put on the recovery from all kinds of disasters so that the damaged infrastructure can be readily and cost-effectively restored $([55], 728)$. As such, according to Bures [23], it may be more acceptable to private companies, whose profit motive makes them very interested in getting their businesses restored and running as soon as possible following any disruption of their production.

\section{Consequences of security provision beyond PMSCs}

While there appears to be a general agreement across social science disciplines that a pluralization of security is taking place, there is considerable disagreement about its impact and implications. On the one hand, in much of the global governance literature pluralization of security is presented largely in positive terms as part of a broader shift from government to governance, because the traditional hierarchical conceptions of government are seen as inadequate when it comes to capturing the geographically, functionally, normatively and institutionally dispersed structure of security provision $[56,57]$. In contrast, various non-hierarchical governance arrangements are viewed positively as presenting numerous opportunities for productive cooperation of multiple 
actors, including private companies, in the provision of security and other traditionally state-provided goods and services (see [3] for a literature review). Similarly, in line with the aforementioned claims by public officials, security governance experts have also pointed out that in response to the emergence of recent security threats, there has been a turn towards new modes of security governance that include a hybrid mix of public and private actors, which rest upon non-hierarchical networks, and rely on soft compliance based on instruments such as peer evaluations or best practices $[5,10,58]$. Because of their flexibility, relative independence from national governments, as well as their ability to include a broad range of participants on equal footing, it is generally assumed that these informal policy structures "are more suitable for tackling governance problems or achieving common goals than more hierarchical and formal strategies" ([59], 118). Such perceived adequateness usually derives from the conceptualization of emerging security threats as more fluid and networked- based, which makes them less susceptible to traditional State responses [60].

On the other hand, several security, sociology and criminology experts have expressed a rather negative view of the increasing pluralization of security in general, and of the growing role of private sector actors in particular. Primarily, this is due to concerns about the repercussions on the provision of security, traditionally conceived as a public good provided by states to all citizens, and/or concerns about the lack of public accountability, oversight, and legitimacy of private sector actors $[5,20]$. In the conflict resolution literature, this critical view is pervasive in numerous studies that investigate the role of private companies in contemporary armed conflicts. Their authors almost unanimously conclude that in areas of weak or failing governmental authority, private companies are often contributors to security problems, rather than to their solutions [61-64]. Moreover, many of the intriguing questions that have been asked concerning the implications of the increasing utilization of services of private military and/or security companies (PMSCs) in the security studies literature are particularly relevant in the context of this special issue. Namely, how does the growing participation of companies whose primary line of business is not security provision impact on the development and running of security policies? Such question implies concerns about depoliticization and commodification of security: as it becomes a commodity capable of being globally exported as a set of technical capabilities and skills, it is increasingly transformed from a political problem requiring welfare social policy and state intervention to a technical problem amenable to private solutions through the logics of cost efficiency $[1,2]$.

Overall, therefore, the existing literature not only points out the growing presence of the private sector in security related activities and critical infrastructures and the consequent transfer of responsibilities from the public sector to companies - it also underlines the expanding neo-liberal approach to security governance, based on a reduction of risk, a perception of the private sector as being more efficient and adequate to deal with recent security threats, and a responsibilization of all sectors of society for collective security. These issues have been further explored by a growing critical literature on neo-liberalism and its restructuring of security governance $[65,66,1,2]$. According to this literature, the mainstreaming of neo-liberal economic policies, the consequent commodification of security and the latter's refashioning as an expertise- dominated field have led to the belief that the private sector is better placed to deal with security threats and risks given its high degree of efficiency. Furthermore, private businesses have also emerged as sites 
of expertise in their own fields, putting them at an advantage, in relation to the State, when dealing with issues of insecurity [33]. This literature voices, however, serious concerns in terms of the private sector's priorities and their incompatibility with the traditional public security and safety priorities of the State [65].

In this special issue, the political, economic and social consequences of this transfer of responsibilities from the public sector to the private one are highlighted in very different areas. Carrapico and Farrand [21] refer to tangible consequences in the area of cyber security where the privacy and data security of Internet users has been put at risk due to a lack of prioritisation of encryption and other security measures. Saldivar and Price [27] argue that the increasing management of the United States' prison industrial complex by private actors has contributed substantially towards the securitization of immigrants and rendered their integration process more difficult. Having benefitted from the state of exception rationale enabled by the War on Drugs, the private prison system reinforced its own role by lobbying political actors for harsher immigration legislation in view to increasing its profits. Biaumet's case study on Burundi [26] suggests that in a transitioning context, where different agents and normativities namely the government, the police, corporate security actors, donor states and institutions, individuals, transnational norms on (private) security and local dynamics - are intertwined in the provision of security, discrepancies between donor discourses and local dynamics remain at work. To a certain extent, these discrepancies reflect the theoretical debate over the state's role in security governance, particularly in postconflict contexts where concerns about democratic oversight, the rule of law and accountability abound.

Finally, Bures' article [23] surveyed three key general challenges of the growing role of private businesses in the provision of security - responsibilization, depoliticization, and commodification. These are important reminders that the engagement of private businesses in the provision of security is always bound to raise a number of profound political dilemmas, which imply the need for (re-)consideration of the more traditional regulatory frameworks in order to safeguard important public goods and/or values. Moreover, since private companies can actually decide not to provide particular security goods and/or services if their provision is deemed unprofitable, there is a clear need for public alternatives for the provision of such security goods and/or services available to all citizens at all times.

\section{Avenues for future research}

As noted above, the key aim of this special issue is to widen the existing debates on security privatization by looking at how and why an increasing number of private actors beyond PMSCs have come to perform various security-related functions. It is therefore important to conclude this introduction by acknowledging that there is considerable room for further research going beyond the ground covered in this special issue, both conceptually and empirically speaking. We would therefore like to encourage further research on the new private actors that are participating in security governance and on the different arrangements that have emerged between those private actors and the public sector. Some of this still to-be-explored ground was covered by other participants in our workshop, at the British International Studies Association 
annual conference in London. We would therefore like to offer here a summary of these insights regarding 1) the types of actors and areas of security, and the 2) conceptual frameworks covered by these unpublished contributions, as indicators of plausible future avenues of research.

The paper by Hendrik Hegemann explored a number of these avenues for further research. In particular, it looked at the participation of private actors in EU civil security governance via two innovative case studies: the EU security research programme and EU guidelines for integrated risk assessments [67]. The author's research suggested a need to investigate different types of private actor involvement, extending beyond the more traditional of concepts delegation, co-regulation and public-private-partnerships. In civil security governance in the EU, where the goal is neither to formally regulate the behaviour of private actors nor to award independent security functions to them, but to draw on the specialised experience and knowledge they have gained, this specifically includes consultation, information exchange, and provision of research funding. Conceptually, these arrangements highlight the plausibility of application of concepts of 'new' or 'experimentalist' governance to the security field with the aim to use the scientific state of the art to develop innovative policy solutions that 'work' and serve the goal of 'better regulation' beyond the intricacies of ideological politics $[68,69]$. The author also suggests that there is a potential value to the concept of 'orchestration' given that international organizations often play a special role in these modes of governance: they 'orchestrate' private actors based on their cross-national overview of relevant expertise in order to leverage their limited powers and resources and increase their autonomy and authority vis-à-vis sceptical states (see [70]).

William Vlcek looked into the privatization of security in the domain of global finance and analyzed the long process that has emerged in the production of money laundering as a crime and the increased application of economic sanctions as a tool for maintaining global peace and security [71]. His research shows that financial firms and a variety of non-financial economic actors are now responsible for surveillance against money laundering and terrorist finance along with the enforcement of economic sanctions, and in particular US economic sanctions. He specifically focused on the numerous consequences stemming from the transfer of this obligation to protect society from the state to private financial actors, along with the responses to government measures enforcing the privatization of financial surveillance. This rational response can be framed as an example for 'riskification' (see [72]), the identification of financial activities and actors that present a high risk as subjects for future financial sanctions and the termination of all business transactions with them. In turn, one unintended consequence from this rational action is to leave these activities and actors outside the global financial system and its financial surveillance mechanisms. As a result, according to Vlcek, the privatisation of financial surveillance may force illegality beyond the scope of that surveillance and circumvent its original objective.

Sarah Komasova explored the concept of airport security and functions of its existing structures at different airports, with primary emphasis on the role, interactions and divergent approaches of public and private actors [73]. In the centre of her inquiry is the question of how the concept of airport security, including its parts and components, is understood and practiced, and how this understanding and practice are influenced by the presence of private actors. She adopts Marc Salter's understanding of airport security 'in terms of passenger, baggage, and airport employees screening; 
perimeter and sterile area access; and terminal security' ([74], 4). In this view, the important actors of airport security are the following: state, airport company shareholders represented by airport management, state employees and serviceman, private security subcontractors and their employees, relevant airlines personal and travellers, further airport buildings and procedures, technology and ideas of security and risk management. In theoretical terms, Komasova's inquiry primarily builds on actornetwork theory and its methodological emphasis on field research, or more precisely, going to the sites of airport security production. In her research project, she is analysing three cases of existing airports security arrangements, each with different interactions between public and private actors, in order to provide a comparative analysis.

Pawel Frankowski and Irma Słomczyńska explored the growing presence of the private sector in space, building a comparative study between companies in the United States and Europe [75]. The conference paper problematised the private sector's approach to data protection and licencing by focusing on privately developed technology such as satellite imagery and satellite remote sensing. The authors also discussed the consequences of this growing presence for global security by asking whether an increased reliance on private capabilities, in a traditional area of state activity, could lead to the emergence of new security threats. One of the particularly interesting aspects of this paper was the mapping of security arrangements in an empirical area that has so far received limited attention. Through their comparison between the US and Europe, the authors uncovered evidence of different security arrangements: in the US, private security companies shape legislation and policy directly, whereas in Europe, the process is still mainly in the hands of the state sector.

Going beyond this special issue, there is a considerable range of actors, both private and public worthy of further exploration. It is the case, namely, of international organisations, which play an important role as brokers for many public-private arrangements. The aforementioned concept of orchestration may offer new insights in this respect since it involves IGOs enlisting intermediary actors on a voluntary basis, by providing them with ideational and material support, to address target actors in pursuit of IGO governance goals. Both the intermediary and target actors may include private businesses and via orchestration, the IGO creates, supports and integrates a multi-actor system of soft and indirect governance geared towards shared goals that neither orchestrator nor intermediaries could achieve on their own [70]. Furthermore, as this special issue pointed out, different policy areas are characterised by different arrangements and, as such, this literature would considerably benefit from expanding the limited range of policies covered so far. Although a lot of these arrangements have been referred to as PPPs, their shape and division of labour can vary widely. We would also like to encourage further research on the political, social, and economic consequences of such arrangements and on the conceptual frameworks used to explain these new arrangements. One such framework this new research agenda could engage with is the nodal governance perspective (see [11]), which has already been successfully utilized for grappling more explicitly and systematically with the 'messy realm of practices and relations' ([76]: 199) between public and private actors in criminology. Some of the topics we believe would also be worth expanding upon are the development of private actors' expertise in this field, how it is framed in the context of security governance, and the insights it reveals about the current economic model of neo-liberalism. 
Acknowledgments The editors of this special issue would like to thank the British International Studies Association for its support in the development of this project, in particular for the funding of the kick-start workshop in June 2015 in London. They would also like to thank all the participants in that workshop for their excellent contributions. Finally, they would also like to thank Raphael Bossong, Asne Aarstad and Gilles Biaumet for their insightful comments, which considerable contributed to the development of this introductory article.

\section{References}

1. Abrahamsen, R., \& Williams, M. C. (2011a). Security beyond the state: private security in international politics. Cambridge University Press: Cambridge.

2. Abrahamsen, R., \& Williams, M. (2011b). Security privatization and global security assemblages. Brown Journal of World Affairs, 18(1), 171-180.

3. Boerzel, T. A., \& Risse, T. (2006). Public-private partnerships: effective and legitimate tools of transnational governance. In E. Grande \& L. W. Pauly (Eds.), Complex sovereignty (pp. 195-216). Toronto University Press: Toronto.

4. Dunn-Cavelty, M., \& Kristensen, K. S. (2008). Securing 'the homeland': critical infrastructure, risk and (in) security. Routledge: London.

5. Krahmann, E. (2005). Security governance and networks: new theoretical perspectives in transatlantic security. Cambridge Review of International Affairs, 18(1), 15-29.

6. Müller-Wille, B. (2004) For our eyes only? Shaping an intelligence community within the EU. Occasional papers no. 50. Paris: Institute for Security Studies.

7. Parker, M., \& Taylor, M. (2010). Financial intelligence: a price worth paying? Studies in Conflict \& Terrorism, 33(11), 949-959.

8. Petersen, K. L. (2013) The corporate security professional: a hybrid agent between corporate and national security. Paper presented at the annual meeting of the ISA's 54th Annual Convention, San Francisco, CA, USA, April 6, 2013. 30.5.2013.

9. Shearing, C., \& Wood, J. (2003). Nodal governance, democracy, and the new “denizens". Journal of Law and Society, 30(3), 400-419.

10. Webber, M., Croft, S., Howorth, J., Terriff, T., \& Krahmann, E. (2004). The governance of European security. Review of International Studies, 30(1), 3-26.

11. Wood, J., \& Dupont, B. (2006). Democracy, society and the governance of security. Cambridge University Press: Cambridge.

12. Ortiz, C. (2007) The private military company: an entity at the centre of overlapping spheres of commercial activity and responsibility. In T. Jager, G. Kummel (Eds.), Private military and security companies: chances, problems, pitfalls and prospects (pp. 55-58). Verlag fur Sozialwissenschaften.

13. Leander, A. (2013). Introduction. In A. Leander (Ed.), Commercialising security in Europe: political consequences for peace operations. PRIO: Routledge.

14. Traynor, I. (2003) The privatization of war, (Global Policy Forum). 19/04/2004. http://www.globalpolicy. org/security/peacekpg/training/1210privatization.htm Guardian (Ed).

15. Avant, D. (2004). The market for force: the consequences of privatizing security 9. Cambridge University Press: Cambridge.

16. Chesterman, S., \& Lehnardt, C. (2007). From mercenaries to market: the rise and regulation of private military companies. Oxford University Press: Oxford.

17. Jäger, T. \& Kümmel, G. (2007) Private military and security companies: chances, problems, pitfalls and prospects. VS Verlag für Sozialwissenschaften.

18. Ortiz, C. (2010). Private armed forces and global security: a guide to the issues. Santa Barbara, Denver, Oxford: Praeger.

19. Percy, S. (2007). Mercenaries: the history of a norm in international relations. Oxford University Press: Oxford.

20. Singer, P. W. (2003). Corporate warriors. The rise of the privatized military industry. Ithaca, NY: Cornell University Press.

21. Carrapico, H. \& Farrand, B. (2016) Dialogue, partnership and empowerment for network and information security: EU policies and private stakeholders. Crime, Law and Social Change, ?? 
22. Bossong, R. \& Wagner, B. (2016) A typology of cybersecurity and public-private partnerships in the context of the EU. Crime, Law and Social Change,??

23. Bures, O. (2016). Contributions of private businesses to the provision of security in the EU: beyond publicprivate partnerships. Crime, Law and Social Change. doi:10.1007/s10611-016-9650-6.

24. Waltz, K. (1999). Globalization and governance. PS: Political Science and Politics, 32(4), 693-700.

25. Aarstad, A. K. (2016) Maritime security and transformations in global governance. Crime, Law and Social Change, ??

26. Biaumet, G. (2016) The sentinel and the rebel. Multi-choice policing in Burundi and the state-centered approach of security sector reform. Crime, Law and Social Change, ??

27. Moreno Saldivar, K. \& Price, B. E. (2016) The social and political impact of the new (private) national security: securitization of immigration in the United States post 9/11. Crime, Law and Social Change, ??

28. Dunn Cavelty, M. (2010). Cyber- threats. In M. Dunn Cavelty \& V. Mauer (Eds.), The routledge handbook of security studies. London and New York: Routledge.

29. The National Commission on Terrorist Attacks Upon the United States (2004) http://govinfo.library.unt. edu/911/report/index.htm. In: The 9/11 Commission report. 21.11.2008.

30. Braithwaite, J. (2008). Regulatory capitalism: how it works, ideas for making it work better. Cheltenham: Edward Elgar.

31. O’Rourke, T. D. (2007) Critical infrastructure, interdependencies, and resilience. The bridge 37,(1), 2229.

32. Bossong, R. (2014). The European programme for the protection of critical infrastructures-metagoverning a new security problem? European Security, 23(2), 210-226.

33. Barrinha, A. \& Carrapico, H. (forthcoming 2016) The internal, the external and the virtual: the EU and the security of cyberspace, in L. Chappell, J. Mawdsley and P. Petrov (Eds.) The EU, Strategy and Security Policy. London and New York: Routledge.

34. De Bruijne, M., \& van Eeten, M. (2007). Systems that should have failed: critical infrastructure protection in an institutionally fragmented environment. Journal of Contingencies \& Crisis Management, 15(1), 1829.

35. European Council (2008) Report of the implementation of the European security strategy: providing security in a changing world. Brussels. December 2008. https:/www.consilium.europa.eu/ueDocs/cms Data/docs/pressdata/EN/reports/104630.pdf. Accessed 4 Apr 2015.

36. Beck, U. (1992). Risk society: towards a new modernity. Sage: London.

37. Garland, D. (2001). The culture of control. Oxford University Press: Oxford.

38. Lee, E. (2009) Homeland security and private sector business: corporation's role in critical infrastructure protection (New York, CRC Press).

39. Bursh, N. E., \& Givens, A. D. (2012). Public-private partnerships in homeland security: opportunities and challenges. Homeland Security Affairs, 8(18), 1-23.

40. Verkuil, P. R. (2007). Outsourcing Sovereignty. Cambridge University Press: Cambridge.

41. Bures, O. (2013). Public-private partnerships in the fight against terrorism? Crime, Law and Social Change, 60(4), 429-455.

42. Minow, M. (2003). Public and private partnerships. Accounting for the new religion. Harvard Law Review, 116(1), 1229-1270.

43. Collier, S. J., \& Lakoff, A. (2008). The vulnerability of vital systems: how critical infrastructure became a security problem. In M. D. Cavelty \& K. S. Kristensen (Eds.), Securing 'the homeland': critical infrastructure, risk and (in) security (pp. 17-39). Routledge: London.

44. Petersen, K. L. (2008). Risk, responsibility and roles redefined: is counterterrorism a corporate responsibility? Cambridge Review of International Affairs, 21(3), 403-420.

45. Bourdieu, P. (1977). Outline of a theory of practice. Cambridge: Cambridge University Press.

46. Bourdieu, P. (1998). Practical reason: on the theory of action. Cambridge: Polity.

47. Verhage, A. (2008). Between the hammer and the anvil? The anti-money laundering-complex and its interactions with the compliance industry. Crime, Law and Social Change, 52, 9-32.

48. Foucault, M., \& Miskowiec, J. (1986). Of other spaces. Diacritics, 16(1), 22-27.

49. Wesseling, M. (2009) In: New Spaces Governing the EU's Fight Against Terrorism Financing. Paper presented at the annual meeting of the ISA's 50th annual convention "exploring the past, anticipating the future,” New York Marriott Marquis, New York City, NY, USA, Feb 15, 2009. 21.2.2010. http://www. allacademic.com/meta/p311342_index.html.

50. Whelan, G. (2012). The political perspective of corporate social responsibility: a critical research agenda. Business Ethics Quarterly, 22(4), 709-737.

51. Moon, J., \& Crane, A. (2005). Corporate citizenship: toward an extended theoretical conceptualization. Academy of Management Review, 30(1), 166-179. 
52. Ougaard, M. (2010). Introducing business and global governance. In M. Ougaard \& A. Leander (Eds.), Business and global governance (pp. 1-36). Abingdon: Routledge.

53. Scherer, A. G., \& Palazzo, G. (2011). The new political role of business in a globalized world: a review of a new perspective on CSR and its implications for the firm, governance and democracy. Journal of Management Studies, 48(4), 899-931.

54. Scherer, A. G., Palazzo, G., \& Matten, D. (2009). Introduction to the special issue: globalization as a challenge for business responsibilities. Business Ethics Quarterly, 19(3), 327-347.

55. Pursiainen, C. (2009). The challenge for European critical infrastructure protection, European. Integration, 31(6), 721-739.

56. Brühl, T. (2001) The privatization of governance systems: on the legitimacy of environmental policy. Paper presented at global environment and the nation state, at Berlin, December 7-8, 2001.

57. Reinicke, W. H., Deng, F. (2000) Critical choices. the United Nations, networks, and the future of global governance. International Development Research Centre, May. Available from: http://www.gppi.net/ fileadmin/user_upload/media/pub/2000/Reinicke_Deng-2000-Critical_Choices.pdf. Accessed 30 Sept 2016.

58. Gill, P. (2006). Not just joining the dots but crossing the borders and bridging the voids: constructing security networks after 11 September 2001. Policing \& Society, 16(1), 27-49.

59. Den Boer, M., Hillerbrand, C., \& Nölke, A. (2008). Legitimacy under pressure: the European web of counter-terrorism networks. Journal of Common Market Studies, 46(1), 101-124.

60. Carrapico, H., Irrera, D., \& Tupman, B. (Eds.) (2015). Criminals and terrorists in partnership: unholy alliance. New York, London: Routledge.

61. Ballentine, K., \& Sherman, J. (2003). The political economy of armed conflict: beyond greed and grievance. CO, Lynne Rienner Publishers: Boulder.

62. Berdal, M., \& Malone, D. M. (2000). Greed and grievance: economic agendas in civil wars. CO, Lynne Rienner: Boulder.

63. Klare, M. T. (2001). Resource wars: the new landscape of global conflict. Owl Books: New York.

64. Musah, A. F. (2002). Privatization of security, arms proliferation and the process of state collapse in Africa. Development and Change, 33(5), 911-933.

65. Price, S. (2011). Worst-case scenario? governance, mediation and the security regime. London. New York: Zed Books Lda.

66. Harvey, D. (2007). A Brief History of Neoliberalism, New Ed edition. ed. OUP Oxford, Oxford; New York.

67. Hegemann, H. (2015) The politics of private actor participation in EU civil security governance: beyond the 'security-industrial complex'? Conference paper presented at the 2015 British International Studies Association, London.

68. Nance, M. T., \& Cortrell, M. P. (2014). A turn toward experimentalism? Rethinking security and governance in the twenty-first century. Review of International Studies, 40(2), 277-301.

69. Sabel, C. F., \& Zeitlin, J. (2010). Experimentalist governance in the European Union: toward a new architecture. Oxford: Oxford University Press.

70. Abbott, A. W., Genschel, P., Snidal, D., \& Zangl, B. (Eds.) (2015). International organizations as orchestrators. Cambridge: Cambridge University Press.

71. Vlcek, W. (2015) Privatising financial surveillance and the 'riskification' of global capital movements. Conference paper presented at the 2015 British International Studies Association, London.

72. Corry, O. (2012). Securitisation and 'riskification': second-order security and the politics of climate change. Millennium - Journal of International Studies, 40(2), 235-258.

73. Komasova, S. (2015) Reassembling airport security: thesis research proposal. Conference paper presented at the 2015 British International Studies Association, London.

74. Salter, M. B. (2008). Politics at the airport. Minneapolis: University of Minnesota Press.

75. Frankowski, P. and Słomczyńska, I. (2015) Outer space and private companies. Consequences for global security. Conference paper presented at the 2015 British International Studies Association, London.

76. Scherer, A. G., Palazzo, G., \& Matten, D. (2009). Introduction to the special issue: globalization as a challenge for business responsibilities. Business Ethics Quarterly, 19(3), 327-347. 